\title{
Analgesic and Anti-inflammatory Activities of Ethanolic Extract of Clerodendrum inerme (L.) Gaertn.
}

\author{
Dipa Khanam ${ }^{1}$, Debashish Deb², Shrabanti Dev ${ }^{1}$, Masum Shahriar ${ }^{3}$, Asish K. Das ${ }^{1}$ \\ and Md. Hassan Kawsar ${ }^{4}$ \\ ${ }^{1}$ Pharmacy Discipline, Khulna University, Khulna, Bangladesh \\ ${ }^{2}$ Biotechnology and Genetic Engineering Discipline, Khulna University, Khulna, Bangladesh \\ ${ }^{3}$ Department of Pharmacy, Jahangirnagar University, Savar, Bangladesh \\ ${ }^{4}$ Department of Pharmacy, State University of Bangladesh
}

\begin{abstract}
Clerodendrum inerme (L.) Gaertn. (Verbenaceae) is very popular among the traditional practitioners in Bangladesh for the treatment of local pain and inflammation, skin diseases, topical burns etc. However, so far no scientific study has been carried out which may support its uses in traditional medicine. In the present study, we evaluated the possible analgesic and anti-inflammatory activities of the ethanol extract of $C$. inerme for the first time. Analgesic activity was assessed by using acetic acid-induced writhing and heat-induced pain in mice and anti-inflammatory activity using xylene-induced ear edema in mice at the doses of 250 and $500 \mathrm{mg} / \mathrm{kg}$ body weight. The extract significantly $(\mathrm{P}<0.05)$ attenuated the acetic acid-induced writhing with the highest activity being observed at 500 $\mathrm{mg} / \mathrm{kg}$ b.w. (45.83\%) comparable to that of diclofenac sodium (57.64\%), the standard drug. A significant dosedependent increase $(\mathrm{P}<0.05)$ of the latency period was also observed in hot plate method. In the xylene-induced inflammation assay, the extract showed significant $(\mathrm{P}<0.05)$ and dose dependant inhibitory effect on the edema formation. These findings indicate that the extract has significant analgesic and anti-inflammatory activities which support the folkloric claim of this plant and thus it has a great potential as source of natural products-derived drug.
\end{abstract}

Key words: Clerodendrum inerme, Analgesic, Anti-inflammatory activity.

\section{Introduction}

Clerodendrum inerme (L.) Gaertn. (Verbenaceae) is a medicinal shrub which usually reaches a height of 3-4 m with closely arranged, almost round, shiny, deep green leaves. The plant is indigenous to India, Philippines, and in the rivers of tropical northern Australia. It is also found in the low laying coastal areas of southern districts in Bangladesh such as Bagerhat, Khulna, Chittagong, Satkhira and the vast area of Sundarban. The plant is commonly grown as hedge. Locally the plant is known as Wild Jasmine (Bangladesh) and traditionally used for the treatment of skin diseases, venereal infections, beriberi, tumors, asthma, topical burns, and rheumatism (Nadkarni, 1976; Kirtikar and Basu, 1975; Rehman et al., 1997). It has anticarcinogenic and antifungal properties as well (Manoharan et al., 2006; Rajasekaran and Ponnusamy, 2006). Its leaves showed antioxidant activity (Chourasiya et al., 2010).. So far a glycoside ester namely verbascoside, a steroidal glycoside [3- $O-\beta$-D-galcatopyranosyl-(24 $\beta)$ ethylcholesta-5, 22, 25-trien], glutinol, two megastigmane glucosides (sammangaosides $\mathrm{A}$ and $\mathrm{B}$ ), an iridoid glucoside (sammangaoside C), a clerodane diterpene (clerodermic acid), friedelin, 5-hydroxy-7,4'-dimethoxyflavone, salvigenin, acacetin, and apigenin have been isolated from this plant (Fauvel et al., 1989; Rehman et al., 1997; Kanchanapoom et al., 2001; Pandey et al., 2005). But up to now no scientific evaluation is reported for the analgesic and anti-inflammatory activities of the ethanol extract of $C$. inerme. So, the present study has been undertaken to evaluate the analgesic activity of the ethanol extract of $C$. inerme using writhing \& hot plate assays, and anti-inflammatory activity using xyleneinduced ear edema method. 


\section{Materials and Methods}

Plant material and extraction: $C$. inerme was collected in November, 2008 from Sundarban district of Khulna, Bangladesh. The plant was identified in Bangladesh National Herbarium, Mirpur, Dhaka (Accession No.-33164). The whole plants of $C$. inerme were pulverized into a coarse powder and approximately $400 \mathrm{~g}$ of was extracted by a Soxhlet apparatus with $70 \%$ aqueous ethanol. The extract was filtered and concentrated by using a rotary evaporator. The concentrated mass was then completely dried with a freeze drier. The percentage yield of the extract was found to be $16.58 \%$ (w/w). An aliquot of dried mass was pulverized to fine powder and suspended in 1\% Tween-80 in water as per dose requirement.

Animals: Swiss albino mice (male), weighting 23-25 $\mathrm{g}$, bred in the animal house of Department of Pharmacy, Jahangirnagar University, Savar, Dhaka, Bangladesh were used for the experiments. All the animals were acclimatized for one week prior to the experiments. The animals were housed under standard laboratory conditions (relative humidity $55-65 \%$, room temperature $25.0 \pm 2{ }^{0} \mathrm{C}$, and $12 \mathrm{~h}$ light dark cycle). They were fed with standard diet (ICDDR,B formulated) and had free access to tap water but were fasted for $12 \mathrm{~h}$ prior to each experiment. All experimental procedures were approved by the ethical committee of Jahangirnagar University, Bangladesh.

Drugs: The drugs and chemicals used in this study include xylene (Sigma-Aldrich Co., UK), 0.6\% acetic acid (Searle, Essex), diclofenac sodium (Square Pharmaceuticals Ltd., Bangladesh), pentazocine (Beximco Pharma Ltd., Bangladesh).

Acetic acid-induced writhing method: Analgesic activity of $C$. inerme was tested using the acetic acidinduced writhing method as described previously (Ahmed et al., 2004) with minor modifications. Experimental animals were randomly divided into four groups denoted as control (group-I), standard drug (group-II), extract 250 $\mathrm{mg} / \mathrm{kg}$ b.w. (group-III) and extract $500 \mathrm{mg} / \mathrm{kg} \mathrm{b.w.} \mathrm{(group-}$ IV) consisting of six mice in each. Each group received a particular treatment like group-I received vehicle (1\% Tween 80 in water, $10 \mathrm{mg} / \mathrm{kg}$ body weight), group-II received standard drug (diclofenac sodium, $10 \mathrm{mg} / \mathrm{kg}$ b.w.) and the other two groups received the sample extract at two different doses. Each mouse was weighed properly and the doses of the extract, standard drug, and control materials were adjusted accordingly. All test samples were administered intraperitonealy. An interval of $30 \mathrm{~min}$ was given to ensure proper absorption of the administered substances. Then the writhing inducing chemical glacial acetic acid solution $(0.6 \%)$ was administered intraperitonealy to each of the animals. After an interval of $5 \mathrm{~min}$, the number of writhing was counted for $10 \mathrm{~min}$. The animals did not always accomplish full writhing, because the animals started to give writhing sometimes but they did not complete it. This incomplete writhing was considered as half writhing. The \% inhibition was calculated using the formula-

Inhibition $(\%)=[($ Mean no. of writhings, control $)-$ (Mean no. of writhings, test)] / (Mean no. of writhings, control) x 100.

Hot-plate method: The hot plate test was used to measure analgesic activity by the method described by Ramasamy and Kumar (2009) with minor modifications. Here, the animal grouping was done in the same way as for the previous test. Group I animals received vehicle ( $1 \%$ Tween 80 in water, $10 \mathrm{mg} / \mathrm{kg}$ body weight), animals of Group II received pentazocine at $5 \mathrm{mg} / \mathrm{kg}$ body weight while animals of Group III and Group IV were treated with 250 and $500 \mathrm{mg} / \mathrm{kg}$ body weight (i.p.) of the crude extract of $C$. inerme. The temperature of a metal surface was maintained at $55 \pm 0.2^{\circ} \mathrm{C}$. Latency to a discomfort reaction (licking, shaking or jumping) was determined before and after drug administration. The cut-off time was fixed to $15 \mathrm{~s}$ to avoid the damage to the paw of the animals (Hasan et al., 2009). The latency was recorded at 0, 30, $60,120,180 \mathrm{~min}$ following oral administration of the agents. The prolongation of the latency times compared with the control was used for statistical evaluation.

Xylene-induced mice ear edema method: Antiinflammatory activity of $C$. inerme was tested using the xylene-induced mice ear edema model as described by Tang et al. (1984). Male Swiss mice were randomly divided into four groups with six mice in each group. Group-I or the control group received only vehicle (1\% Tween 80 in water, $10 \mathrm{mg} / \mathrm{kg}$ body weight), Group-II or the positive control group received standard drug diclofenac sodium at a dose of $10 \mathrm{mg} / \mathrm{kg}$ body weight and the test groups (Group III and IV) were treated with suspension of $C$. inerme extract at the doses of 250 and 
$500 \mathrm{mg} / \mathrm{kg}$ body weight respectively. After $1 \mathrm{~h}$ of the intraperitoneal administration of the vehicle, drug and extract, xylene $(0.01 \mathrm{ml})$ was applied to the anterior and posterior surfaces of the right ear of each mouse. Mice were sacrificed $1 \mathrm{~h}$ after xylene application and both ears were removed. Circular sections of both treated and untreated ears were taken using a $7 \mathrm{~mm}$ diameter cork borer and weighed. The difference in weight between left untreated ear section and right treated ear section was calculated.

Statistical analysis: Student's $t$-test was used to determine significance of difference between the control group and experimental groups.

\section{Results}

Writhing assay: The intraperitoneal administration of C. inerme caused significant inhibition of writhing effect in mice induced by the acetic acid. At both doses the extract inhibited the acetic acid-induced writhing. At 250 $\mathrm{mg} / \mathrm{kg}$ b.w. the extract caused $26.39 \%$ of writhing inhibition and at $500 \mathrm{mg} / \mathrm{kg}$ b.w. it produced $45.83 \%$ of inhibition compared as to control whereas the standard analgesic drug, diclofenac sodium revealed $57.64 \%$ of inhibition (Table 1).

Hot-plate test: The extract of $C$. inerme when intraperitoneally injected with a dose of 250 and 500 $\mathrm{mg} / \mathrm{kg}$ body weight in mice showed significant analgesic activity in hot plate method as supported by increase in latency time. The increase in latency was found to be dose dependent. At both the doses, the extract showed significant analgesic activity when compared to control; however, it was the maximum at $500 \mathrm{mg} / \mathrm{kg} \mathrm{b}$.w. and was comparable with the standard drug (Table 2).

Xylene-induced ear edema in mice: In the xyleneinduced ear edema model mice, the ethanol extract of $C$. inerme displayed significant and dose-dependent inhibitory effect on the edema formation. For the extract, maximum inhibitory effect $(25.54 \%)$ was found at the dose of $500 \mathrm{mg} / \mathrm{kg}$ body weight which was comparable to that of the standard drug, diclofenac sodium that demonstrated $29.4 \%$ at the dose of $10 \mathrm{mg} / \mathrm{kg}$ body weight (Table 3).

Table 1. Analgesic activity of $C$. inerme in writhing test.

\begin{tabular}{lccc}
\hline Groups & Dose (mg/kg b.w.) & $\begin{array}{c}\text { Number of writhing } \\
(\text { mean } \pm \text { SEM) }\end{array}$ & Inhibition (\%) \\
\hline I. Control (Vehicle) & 10 & $28.8 \pm 1.36$ & - \\
II. Diclofenac Sodium & 10 & $12.2 \pm 0.86$ & $57.64^{*}$ \\
III. Extract of $C$. inerme & 250 & $21.2 \pm 1.07$ & $26.39^{*}$ \\
IV. Extract of $C$. inerme & 500 & $15.6 \pm 0.93$ & $45.83^{*}$ \\
\hline
\end{tabular}

All values are expressed as mean $\pm \mathrm{SEM} ; \mathrm{n}=6, * \mathrm{P}<0.05, * * \mathrm{P}<0.01$, significant compared to control.

Table 2. Analgesic activity of $C$. inerme in hot plate test.

\begin{tabular}{|c|c|c|c|c|c|c|}
\hline \multirow[t]{2}{*}{ Groups } & \multirow{2}{*}{$\begin{array}{c}\text { Dose } \\
\text { (mg/kg b.w.) }\end{array}$} & \multicolumn{5}{|c|}{ Reaction time in seconds at time } \\
\hline & & $0 \mathrm{~min}$ & $30 \mathrm{~min}$ & $60 \mathrm{~min}$ & $120 \mathrm{~min}$ & $180 \min$ \\
\hline I. Control (Vehicle) & 10 & $8.62 \pm 0.2$ & $8.46 \pm 0.21$ & $8.34 \pm 0.22$ & $9.01 \pm 0.22$ & $8.69 \pm 0.2$ \\
\hline II. Pentazocine & 5 & $8.69 \pm 0.27$ & $10.43 \pm 0.31^{b}$ & $14.63 \pm 0.81^{b}$ & $17.25 \pm 0.75^{b}$ & $14.53 \pm 0.63^{b}$ \\
\hline III. Extract of $C$. inerme & 250 & $8.73 \pm 0.24$ & $9.11 \pm 0.1^{\mathrm{a}}$ & $9.75 \pm 0.4^{\mathrm{a}}$ & $11.37 \pm 0.64^{\mathrm{a}}$ & $10.14 \pm 0.48^{\mathrm{a}}$ \\
\hline IV. Extract of $C$. inerme & 500 & $8.76 \pm 0.24$ & $9.16 \pm 0.21^{\mathrm{a}}$ & $11.46 \pm 0.71^{\mathrm{a}}$ & $11.37 \pm 0.77^{\mathrm{b}}$ & $12.39 \pm 0.67^{b}$ \\
\hline
\end{tabular}

All values are expressed as mean $\pm \mathrm{SEM} ; \mathrm{n}=6,{ }^{\mathrm{a}} \mathrm{P}<0.05,{ }^{\mathrm{b}} \mathrm{P}<0.01$, significant compared to control. 
Table 3. Effect of ethanol extract from $C$. inerme on xylene induced ear edema in mice.

\begin{tabular}{lccc}
\hline Groups & $\begin{array}{c}\text { Dose }(\mathrm{mg} / \mathrm{kg} \\
\text { b.w.) }\end{array}$ & $\begin{array}{c}\text { Increased weight } \\
\text { (mean } \pm \text { SEM) }(\mathrm{mg})\end{array}$ & $\begin{array}{c}\% \text { of } \\
\text { inhibition }\end{array}$ \\
\hline I. Control (Vehicle) & 10 & $8.3 \pm 0.27$ & \\
II. Diclofenac Sodium & 10 & $5.86 \pm 0.42$ & $29.4^{* *}$ \\
III. Extract of C. inerme & 250 & $7.12 \pm 0.3$ & $13.25^{*}$ \\
IV. Extract of C. inerme & 500 & $6.18 \pm 0.31$ & $25.54^{* *}$ \\
\hline
\end{tabular}

All values are expressed as mean $\pm \mathrm{SEM} ; \mathrm{n}=6,{ }^{*} \mathrm{P}<0.05, * * \mathrm{P}<0.01$, significant compared to control.

\section{Discussion}

In this study, the analgesic and anti-inflammatory activities of the ethanol extract of whole plant of $C$. inerme were evaluated to verify the claims made in folk medicine. Acetic acid-induced writhing and hot plate method were used to screen the analgesic activity. The mouse writhing assay is a simple, reliable and rapid method for evaluating peripheral type of analgesic action but also used for testing centrally acting analgesics (Trongsakul et al., 2003). Acetic acid induces pain through the activation of chemosensitive nocireceptor or irritation of the visceral surface, thereby leading to the liberation of bradykinins, histamine, prostaglandins and serotonins (Mate et al., 2008; Ayanwuyi et al., 2009). According to some researchers, the analgesic response can also be due to lipoxygenase products (Levini et al., 1984). Therefore, inhibition of acetic acid-induced writhing by the extract (Table 1) may be due to inhibition of synthesis or action of above mentioned mediators or inhibition of synaptic transmission of painful messages to the central nervous system.

In case of chemical pain stimuli both central and peripheral analgesics respond by inhibiting the number of contractions induced by the chemicals but for heat induced pain method only centrally acting analgesics respond through increasing the reaction time (García et al., 2004). The results from the hot plate test (Table 2) showed that the extract of $C$. inerme significantly increased the basal reaction time of animals towards the thermal source in a dose-dependent manner. Therefore, it can be claimed that the extract exhibits both central and peripheral analgesia.

Xylene-induced acute inflammation of the mouse ear has generally been used as one of the classic methods for detecting the efficacy of anti-inflammatory agents (Hosseinzadeh et al., 2003; Kou et al., 2005). Histopathologically topical application of xylene causes acute inflammation which is associated with severe vasodilation and edematous changes of skin (Ho et al., 2008; Puerta et al., 1996; Kim et al., 2007; Kou et al., 2003; Rotelli et al., 2003). According to present findings (Table 3), it can be claimed that the extract of $C$. inerme may exhibit anti-inflammatory activity through reducing vasodilation as well as improving edematous condition.

The results of the present investigation suggest that the ethanol extract of $C$. inerme does possess significant analgesic and anti-inflammatory activities in mice. These findings support its folkloric use in pain and inflammatory conditions. Further detailed studies are, however, necessary to identify the active principle(s) and exact mechanism(s) behind these pharmacological properties.

\section{Acknowledgements}

Sincere thanks and gratitude to Khulna University authority for providing adequate financial support to carry out the research work. We are also thankful to Department of Pharmacy, Jahangirnagar University for providing laboratory facilities and necessary reagents during this study.

\section{References}

Ahmed F, Selim MST, Das AK, Choudhuri MSK. 2004. Antiinflammatory and analgesic activities of Lipia nodiaflora Linn. Pharmazie 59, 329-30.

Ayanwuyi, L.O., Yaro, A.H. and Abodunde, O.M. 2010. Analgesic and anti-inflammatory effects of the methanol stem bark extract of Prosopis africana. Pharm. Biol. 48, 296-99.

Chourasiya, R.K., Jain, P.K., Jain, S.K., Nayak, S.S. and Agrawal, R.K. 2010. In vitro antioxidant activity of Clerodendron inerme (1.) Gaertn leaves. RJPBCS 1, 119.

Fauvel, M.T., Gleye, J. and Andary, C. 1989. Verbascoside: A constitute of Clerodendrum inerme. Planta Med. 55, 57. 
García, M.D., Fernandez, M.A., Alvarez, A. and Saenz, M.T. 2004. Antinociceptive and anti-inflammatory effect of the aqueous extract from leaves of Pimenta racemosa var. ozua (Mirtaceae). J. Ethnopharmacol. 91, 69-73.

Hasan, S.M.R., Jamila, M., Majumder, M.M., Akter, R., Hossain, M.M., Mazumder, M.E.H., Alam, M.A., Jahangir, R., Rana, M.S., Arif, M. and Rahman, S. 2009. Analgesic and antioxidant activity of hydromethanolic extract of Mikania scandens (L.) willd. leaves. Am. J. Pharmacol. Toxicol. 4, 1-7.

Ho, C.K., Dong, K.H., Wook, L.B., Kyoung, L.M. and Sae, K.K. 2008. Effects of magnetic infrared laser on xylene induced acute inflammation in mice. J. Phys. Ther. Sci. 20, 255-59.

Hosseinzadeh, H., Haddadkhodaparast, M.H. and Arash, A.R. 2003. Antinociceptive, antiinflammatory and acute toxicity effects of Salvia leriifolia Benth seed extract in mice and rats. Phytother. Res. 17, 422-25.

Kanchanapoom, T., Kasai, R., Chumsri, P., Hiraga, Y. and Yamasaki, K. 2001. Megastigmane and iridoid glucosides from Clerodendrum inerme. Phytochemistry, 58, 333-36.

Kim, H.D., Cho, H.R., Moon, S.B., Shin, H.D., Yang, K.J., Park, B.R., Jang, H.J., Kim, L.S., Lee, H.S. and Ku, S.K. 2007. Effects of beta-glucan from Aureobasidium pullulans on acute inflammation in mice. Arch Pharm. Res. 30, 323-28.

Kirtikar, K.R. and Basu, B.D. 1975. Clerodendron inerme (L.) Gaertn. In: Mhaskar KS, Blatter E, Caius JF, eds. Indian Medicinal Plants. Allahabad, India, Lalif Mohan Basu. 1945-1947.

Kou, Jm, Ma, Rm, Zhu, Dm and Yan, Y. 2003. Blood-activating and anti-inflammatory actions of Polygala fallax. Zhong Yao Cai, 26, 268-71.

Kou, J., Ni, Y., Li, N., Wang, J., Liu, L. and Jiang, Z.H. 2005. Analgesic and anti-inflammatory activities of total extract and individual fractions of Chinese medicinal ants Polyrhachis lamellidens. Biol. Pharm. Bull. 28, 176-80.

Levini, J.D., Lau, W., Kwait, G. and Goetzl, E.J. 1984. Leukotnene B4 produces hyperalgesia that is dependent on the polymorphonuclear leucocytes. Sciences 225 , 743-45.
Manoharan, S., Kavitha, K., Senthil, N. and Renju, G.L. 2006. Evaluation of anticarcinogenic effects of Clerodendrum inerme on 7, 12-dimethylbenz (a) anthracene-induced hamster buccal pouch carcinogenesis. Singapore Med. J, 47, 1038.

Mate, G.S., Naikwade, N.S., Magdum, C.S., Chowki, A.A. and Patil, S.B. 2008. Evaluation of analgesic activity of Cissus quadrangularis on albino mice. Intl. J. Green Pharm. 2, 118-21.

Nadkarni, K.M. 1976. Indian Materia Medica. New Delhi, India: Population Prakashan, Vol. 1, pp. 283-84.

Pandey, R., Verma, R.K. and Gupta, M.M. 2005. Neo-clerodane diterpenoids from Clerodendrum inerme. Phytochemistry 66, 643-48.

Puerta, D.L., Martinez, R.E., Bravo, L. and Ahumada, M.C. 1996. Effect of silymarin on different acute inflammation models and on leukocyte migration. J. Pharm. Pharmacol. 48, 96870 .

Rajasekaran, A. and Ponnusamy, K. 2006. Antifungal activity of Clerodendrum inerme (L) and Clerodendrum phlomidis (L). Turk. J. Biol. 30, 139-42.

Ramasamy, M.S. and Kumar, S.S. 2009. Anti-inflammatory, analgesic and central nervous system depressant activities of marine bacterial extracts. J. Pharmacol. Toxicol. 4, 15259 .

Rehman, A.U., Begum, S., Saied, S., Choudhary, M.I. and Akhtar, F. 1997. A steroidal glycoside from Clerodendron inerme. Phytochemistry 45, 1721-22.

Rotelli, A.E., Guardia, T. and Juarez, A.O. 2003. Comparative study of flavonoids in experimental models of inflammation. Pharmacol. Res. 48, 601-06.

Tang, X.C., Lin, Z.G., Cai, W., Chen, N. and Shen, L. 1984. Anti-inflammatory effect of 3-acetylaconitine. Acta Pharm. Sinica 5, 85-89.

Trongsakul, S.A., Panthong, D., Kanjanpothi, D. and Taesotikul, T. 2003. The analgesic, antipyretic and anti-inflammatory activity of Diospyros variegata Kruz. J. Ethnopharmacol. $\mathbf{8 5}, 221-25$. 